\title{
Electrochemical Corrosion Properties of YSZ Coated AA1050 Aluminium Alloys Prepared by Aerosol Deposition
}

\author{
Hyun Sam Ryu, Tae Seop Lim, Jungho Ryu,* Dong-Soo Park,* and Seong-Hyeon Hong ${ }^{\dagger}$ \\ WCU Hybrid Materials Program, Department of Materials Science and Engineering and Center for Iron and Steel Research, Seoul National \\ University, Seoul 151-744, Korea \\ *Functional Ceramics Research Group, Korea Institute of Materials Science (KIMS), Changwon 641-831, Korea \\ (Received July 25, 2011; Revised August 8, 2011; Accepted August 16, 2011)

\section{에어로졸 증착법에 의한 YSZ 코팅된 $\mathrm{AA1050}$ 알루미늄 합금의 전기화학적 부식 특성} \\ 유현삼 · 임태섭 · 류정호* · 박동수* · 홍성현 \\ 서울대학교 재료공학부 \\ *재료연구소 기능세라믹연구그룹 \\ (2011년 7월 25일 접수 ; 2011년 8월 8일 수정 ; 2011년 8월 16일 승인)
}

\begin{abstract}
Yttria stabilized zirconia (YSZ) coating was formed on AA1050 Al alloys by aerosol deposition (AD), and its electrochemical corrosion properties were investigated in $3.5 \mathrm{wt} \% \mathrm{NaCl}$ and $0.5 \mathrm{M} \mathrm{H}_{2} \mathrm{SO}_{4}$ solutions. The crack-free, dense, and $\sim 5 \mu \mathrm{m}$ thick YSZ coating was successfully obtained by AD. The as-deposited coating was composed of cubic-YSZ nanocrystallites of $\sim 10 \mathrm{~nm}$ size. The potentiodynamic test indicated that the YSZ coated Al alloy had much lower corrosion current densities $\left(2 \mathrm{nA} / \mathrm{cm}^{2}\right)$ by comparison to uncoated sample and exhibited a passive behavior in anodic branch. Particularly, a pitting breakdown potential could not be identified in $\mathrm{H}_{2} \mathrm{SO}_{4}$. EIS tests revealed that the impedance of YSZ coated sample was $\sim 10^{6} \Omega \mathrm{cm}^{2}$ in $\mathrm{NaCl}$ and $\sim 10^{7} \Omega \mathrm{cm}^{2}$ in $\mathrm{H}_{2} \mathrm{SO}_{4}$, which was about 3 or 4 orders of magnitude higher than that of uncoated sample. Consequently, the corrosion resistance of $\mathrm{Al}$ alloy had been significantly enhanced by the YSZ coating.
\end{abstract}

Key words: AA1050 aluminium alloy, Aerosol deposition, Corrosion property, $\mathrm{NaCl}, \mathrm{H}_{2} \mathrm{SO}_{4}$

\section{1. 서 론}

알루미늄의 비중은 2.7로서 현재 공업용 금속 중 마그네 슘 $(\mathrm{Mg})$ 다음으로 가벼운 금속인 동시에 주조가 용이하고 다른 금속과 잘 합금되며, 상온 및 고온에서 가공이 용이 하고 전기, 열의 양도전체의 특성을 가지기 때문에 알루 미늄 및 알루미늄 합금은 항공 우주 산업이나 가정용 기물 외에 일반 공업용 차량, 토목, 건축, 조선, 화학 및 식품 등 많은 공업 분야에 널리 사용된다. ${ }^{1)}$ 알루미늄은 $\mathrm{pH} 4.5$ 8.5의 환경에서는 산화 피막이 모재를 보호하기 때문에 내부식 성이 우수하지만, 높은 이온화 경향 때문에 $\mathrm{Fe}, \mathrm{Cu}, \mathrm{Pb}$ 등과 접촉하면 쉽게 부식되는 단점이 있다. ${ }^{1-3)}$ 비열처리계 알루 미늄 합금 중에 순도가 $99.0 \%$ 이상인 1000 계열은 순도가 높기 때문에 다른 합금에 비해 낮은 강도를 갖지만, 내부 식성, 광의 반사성, 열 도전성이 우수하고 용접 및 성형

\footnotetext{
${ }^{\dagger}$ Corresponding author : Seong-Hyeon Hong

E-mail : shhong@snu.ac.kr

Tel : +82-2-880-1503 Fax : +82-2-884-1413
}

가공성이 용이하다. 그러나 알루미늄 보다 귀한 이종 금속 과 접촉하면, 낮은 전극 전위 $\left(\mathrm{Al}^{3+}+3 \mathrm{e}^{-} \rightarrow \mathrm{Al} ;-1.66 \mathrm{~V}\right.$ vs. $\mathrm{SHE}$ ) 때문에 갈바닉 작용에 의해 쉽게 부식되고 유기산 에는 비교적 안정적이나 무기산에는 쉽게 부식되는 단점이 있다. ${ }^{2,3)}$ 그러므로 1000 계열의 알루미늄 합금에 의해 제 조된 기구들이 이종 금속과의 용접 후 장시간 유지 되거나 산성비와 같은 부식 환경에 노출되면 용접 부위의 부식 작용에 의해서 변형이 일어나거나 표면이 쉽게 부식 될 수 있다. 따라서 AA1050 Al 합금의 부식 저항성을 향상 시키 기 위하여 다양한 표면처리 기술이 연구되고 있다. ${ }^{3,4)}$ 크 로메이트계 화성 처리법은 알루미늄의 가장 대표적인 표 면처리 기술로 내식성 향상에 매우 효과적이지만, 공정 중 에 독성을 갖는 6 가 크롬이 함유된 생성물이 발생하기 때 문에 최근에는 비크로메이트계 화성처리로 전환되고 있 다. ${ }^{3-5)}$ 그러나 비크로메이트계 처리에 의해서 형성된 코 팅층은 크롬산계 코팅층에 비해서 낮은 내식성을 나타내 며, 장기간 안정성 및 모재와의 낮은 접착강도가 단점으 로 지적되고 있다. 
$\mathrm{ZrO}_{2}$ 는 뛰어난 내화도, 높은 화학적 안정성, 내마모성, 부식 저항성 때문에 다양한 금속의 코팅재료로서 적용되고 있다. ${ }^{6-10)} \mathrm{ZrO}_{2}$ 를 이용하여 $\mathrm{Al}$ 합금의 내식성을 향상시킨 연구 결과에 따르면, 얇은 $\mathrm{ZrO}_{2}$ 및 $\mathrm{SiO}_{2}-\mathrm{ZrO}_{2}$ 세라믹 층은 sol-gel 법에 의해서 $\mathrm{Al}$ 합금 위에 형성되어지고 $\mathrm{Al}$ 합금의 내부식성은 표면 코팅층에 의해서 크게 증가하였으며, $8,11,12)$ 플라즈마 전해 산화(PEO)법을 이용하여 다공질 구조의 $\mathrm{PEO}$ 층 표면에 $\mathrm{ZrO}_{2}$ 나노 분말을 형성시킴으로써 산화층의 부식 저항성을 더욱 증가시켰다. ${ }^{13)}$ 그러나 sol-gel 공정은 코팅 층의 두께를 조절하는데 어려움이 있고 수 마이크로미터의 코팅층을 형성하기가 어려우며, 코팅층의 결정화를 위해 서는 추가적인 열처리가 필요하다. $\mathrm{PEO}$ 공정에 형성된 산 화층은 수 마이크로 미터의 코팅층 때문에 대체로 부식 특 성이 양호하지만, 미세 기공과 균열이 존재하는 표면의 다 공질 층은 부식저항성 및 내마모성을 감소시키고 $\mathrm{ZrO}_{2}$ 단일 피막을 형성하는 것은 불가능하다. 이러한 단점을 극복하기 위한 대안으로, 상온에서 세라믹 층을 손쉽게 형성 할 수 있는 에어로졸 증착(aerosol-deposition)법이 크게 주목 받고 있다. ${ }^{14)} \mathrm{AD}$ 기술은 에어로졸 상태의 원료 분말이 에어로 졸 챔버와 증착 챔버 간에 형성된 압력차에 의해 가속화된 후, 기판에 빠르게 충돌하여 후막을 형성하는 기술로서, 결함이 없고 치밀한 세라믹 코팅층을 비교적 광범위한 두 께 $(1 \sim 100 \mu \mathrm{m})$ 로 빠르게 증착 할 수 있다. ${ }^{14,15)}$ 또한, 상온에서 증착이 가능하기 때문에 금속, 세라믹, 경질 고분자 등의 다양한 기판에 대해 적용이 가능하다. 이러한 장점 때문에 $\mathrm{AD}$ 를 이용한 $\mathrm{YSZ},{ }^{7)} \mathrm{Pb}(\mathrm{Zr}, \mathrm{Ti}) \mathrm{O}_{3}(\mathrm{PZT}),{ }^{16)} \mathrm{Al}_{2} \mathrm{O}_{3},{ }^{17)} \mathrm{TiO}_{2}{ }^{18)}$ HA-carbon nanotube ${ }^{19)}$ 등과 같은 다양한 세라믹 코팅층 개 발이 전자기기, 생체 재료, 압전 재료, 광학 재료, 고체 연료 전지, 구조 재료 등에 대한 적용을 위하여 활발히 연구되고 있다. 그러나 현재까지 $\mathrm{AD}$ 코팅 기술을 적용하여 $\mathrm{Al}$ 합금 의 내부식성 향상에 대한 연구는 보고된 적이 없다.

본 연구에서, $\mathrm{AD}$ 방법을 이용하여 yttria stabilized zirconia (YSZ) 피막을 $\mathrm{AA} 1050 \mathrm{Al}$ 합금 위에 증착 하였으며, $3.5 \mathrm{wt} \%$ $\mathrm{NaCl}$ 수용액과 $0.5 \mathrm{M} \mathrm{H}_{2} \mathrm{SO}_{4}$ 수용액에서 동전위 실험 (potentiodynamic test)과 임피던스 분광법 실험(electrochemical spectroscopy test)을 실시하여 그들의 전기화학적 부식 특 성을 고찰하였다.

\section{2. 실험방법}

본 연구에 사용된 알루미늄 합금(AA1050)의 화학적 조 성은 Table 1에 나타내었다. AA1050 시료는 가로 $50 \mathrm{~mm}$, 세로 $24 \mathrm{~mm}$, 두께 $2.5 \mathrm{~mm}$ 의 판재로 가공하였고, 에어로졸
증착을 수행하기 전에 시편의 표면은 $\mathrm{SiC}$ 페이퍼 \#2000을 이용하여 균일하게 연마하였다. 고르게 연마된 시편은 초 음파를 이용하여 알코올로 세척한 후 건조를 실시하였다. 상용화된 YSZ 분말(FYT13.0-005H, Unitec Ceramic, Stafford, $\mathrm{UK})$ 은 에어로졸 증착의 원료 분말로써 사용하였고, 레이저 회절 방식을 채용한 입도 분석기(HELOS \& RODOS, Windox 5, Sympatec GmbH, Clausthal-Zellerfeld, Germany) 에 의해 측정된 분말의 평균 입자 크기는 $1.4 \mu \mathrm{m}$ 이다. 원료 분말은 에어로졸 flow를 형성하기 위하여 에어로졸 챔버 내에서 캐리어 가스(medical grade dry air, flow rate: 30 $1 / \mathrm{min}$ )와 혼합되고, 에어로졸 flow는 튜브를 통해서 노즐로 이송된다. 증착 챔버는 기계식 승압기가 달린 회전 펌프에 의해 진공 상태로 유지되며, 노즐로 이송된 에어로졸은 노즐과 증착 챔버 사이의 압력차에 의해서 증착 챔버안으로 빠르게 분사 된다. 본 실험에서, 증착 챔버 내에 있는 AA1050 $\mathrm{Al}$ 합금은 노즐로부터 $5 \mathrm{~mm}$ 떨어진 곳에 위치하였으며, 가속화된 YSZ 분말의 충돌로 인해서 기판 표면에 치밀한 $\mathrm{YSZ}$ 코팅층이 상온에서 형성되었다. 증착면적은 가로 $25 \mathrm{~mm}$, 세로 $20 \mathrm{~mm}$ 이고, 코팅층 두께는 3 에서 $5 \mu \mathrm{m}$ 의 범위로 조 절하였다. 증착된 코팅층의 상 분석을 위해 $\mathrm{X}$ 선 회절(XRD, M18XHF-SRA)을 이용하였고, 코팅층의 표면 및 단면 형상 은 주사 전자 현미경(SEM, JSM-5600, JEOL, Tokyo, Japan) 을 이용하여 확인하였다. 코팅층의 미세조직 특성은 고 분 해능 투과 전자 현미경(HRTEM, JEM-3000F, JEOL)을 이 용하여 조사하였다. 에어로졸 증착된 $\mathrm{AA} 1050 \mathrm{Al}$ 합금의 부식 거동을 평가하기 위하여 코팅된 시편과 코팅되지 않은 시편에 대한 전기화학적 부식 실험을 $\mathrm{pH} 7.0$ 의 해수 농도의 $3.5 \mathrm{wt} \% \mathrm{NaCl}$ 수용액과 $\mathrm{pH} 1.5$ 의 $0.5 \mathrm{M} \mathrm{H}_{2} \mathrm{SO}_{4}$ 수용액에서 각각 진행하였다. 모든 전기화학적 실험은 세 개의 전극 구 조를 갖는 $250 \mathrm{~mL}$ 용적의 Flat cell을 이용하여 실시하였다. 가로, 세로 각각 $20 \mathrm{~mm}$ 크기의 백금 sheet는 상대전극(counter

Table 2. Results of Potentiodynamic Corrosion Tests for Uncoated AA1050 Al Alloys and YSZ Coated AA1050 $\mathrm{Al}$ Alloys in $3.5 \mathrm{wt} \% \mathrm{NaCl}$ and $\mathrm{H}_{2} \mathrm{SO}_{4}$ Solutions

\begin{tabular}{cccccc}
\hline Solutions & Samples & $\begin{array}{c}\beta \mathrm{a} \\
(\mathrm{mV})\end{array}$ & $\begin{array}{c}\beta \mathrm{c} \\
(\mathrm{mV})\end{array}$ & $\begin{array}{c}\mathrm{E}_{\text {corr }} \\
(\mathrm{mV})\end{array}$ & $\begin{array}{c}\mathrm{i}_{\text {corr }} \\
\left(\mathrm{nA} / \mathrm{cm}^{2}\right)\end{array}$ \\
\hline $\begin{array}{c}3.5 \mathrm{wt} \% \\
\mathrm{NaCl}\end{array}$ & uncoated & 33.9 & 105.1 & -760.2 & 557.4 \\
\hline $\begin{array}{c}0.5 \mathrm{M} \\
\mathrm{H}_{2} \mathrm{SO}_{4}\end{array}$ & YSZ-coated & 193.2 & 196.6 & -882.8 & 2.5 \\
\hline
\end{tabular}

Table 1. Chemical Composition of AA1050 Al Alloy (in wt $\%$ )

\begin{tabular}{cccccccccc}
\hline & $\mathrm{Fe}$ & $\mathrm{Si}$ & $\mathrm{Cu}$ & $\mathrm{Mg}$ & $\mathrm{Mn}$ & $\mathrm{Cr}$ & $\mathrm{Ti}$ & $\mathrm{Etc}$ & $\mathrm{Al}$ \\
\hline $\mathrm{AA} 1050$ & 0.305 & 0.076 & $<0.005$ & $<0.005$ & $<0.005$ & $<0.005$ & 0.017 & $<0.05$ & Remains \\
\hline
\end{tabular}


electrode)으로 이용하였고 포화 칼로멜 전극(SCE)은 기준 전극(reference electrode)으로 이용하였다. 각각의 전해 용 액에서 작업 전극(working electrode)은 $1 \mathrm{~cm}^{2}$ 의 면적으로 노출하였고 실험은 상온에서 진행하였다. 동전위 분극 실험 은 EG\&G 포텐시오 스텟/갈바노 스텟(model 273)을 이용 하여 실시하였으며, 측정된 결과는 부식 소프트웨어(model 352)를 이용하여 분석하였다. 동전위 분극 실험을 실시하기 전에, 개방 회로 전위(OCP, open-circuit potential)의 안정화를 위해서 약 10 분 동안 유지하였으며, 분극 곡선은 $-1.2 \mathrm{~V} / \mathrm{SCE}$ 에서 $1 \mathrm{~V} / \mathrm{SCE}$ 의 범위에서 얻어졌고 실험은 $1 \mathrm{mV} / \mathrm{s}$ 의 스캔 속도로 수행하였다. 전해 용액 내에서 약 20 분의 안정화 이 후, 전기화학적 임피던스 분광법(EIS) 실험은 IM 6 (Zahner Electrick)를 이용하여, $\mathrm{OCP}$ 대비 $10 \mathrm{mV}$ 의 ac 전압이 인가된 조건 하에서 $10^{6} \mathrm{~Hz}$ 에서 $0.1 \mathrm{~Hz}$ 의 주파수 범위에서 실시하 였다. 모든 전기화학적 부식 실험은 적어도 5 회 이상 반복 하여, 재현성과 신뢰도를 확보하였다.

\section{3. 결과 및 고찰}

\section{1. $\mathrm{AD}$ 피막층의 상 및 미세조직}

에어로졸 증착법에 의해 $\mathrm{YSZ}$ 코팅된 $\mathrm{AA} 1050 \mathrm{Al}$ 합금 의 상분석을 위하여 코팅되지 않은 AA1050 Al 합금 기 판, $\mathrm{YSZ}$ 원료 분말, 코팅된 $\mathrm{AA} 1050 \mathrm{Al}$ 합금 시편의 $\mathrm{X}$ 선 회절 분석을 수행하고 그 결과를 Fig. 1에 나타내었다. 세 라믹 코팅층은 결정화되었고 기판과 관련된 회절 피크를 제외한 모든 피크는 cubic 구조의 YSZ (yttria stabilized zirconia)와 관련되었다. 그러나 $\mathrm{YSZ}$ 원료 분말의 회절 패 턴과 비교하면, 코팅된 $\mathrm{AA} 1050 \mathrm{Al}$ 합금의 회절 피크의 위 치는 약간 낮은 각도로 이동했으며, 회절 피크의 모양도 좀 더 넓어졌음을 확인할 수 있다. 회절 피크의 이동과 회

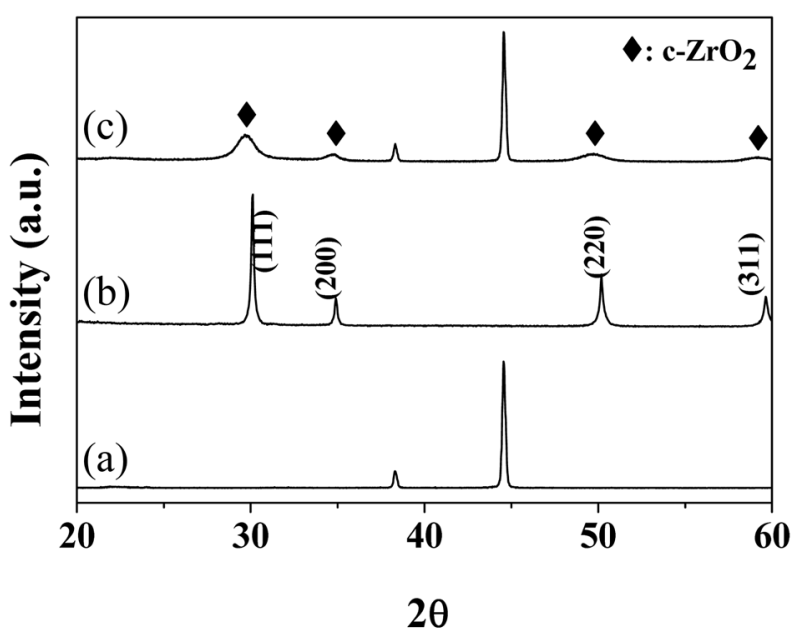

Fig. 1. XRD patterns of (a) uncoated AA1050 Al alloy substrate, (b) starting YSZ powder, and (c) YSZ coated AA1050 Al alloy.
절 피크의 퍼짐 현상은 $\mathrm{AD}$ 법에 의해 증착된 코팅층에서 흔히 관찰되며, 이러한 회철 피크의 특징은 $\mathrm{AD}$ 과정 동안 에 결정질 크기의 감소와 결정질의 불균일한 뒤틀림에 의 해서 기인되는 것으로 알려져 있다. ${ }^{14)}$ 본 연구에서, 회절 피 크의 퍼짐 현상이 결정립 크기의 감소에서 기인되었다고 가 정한다면 Scherer 방정식에 의해 계산된 결정립 크기는 약 $7 \mathrm{~nm}$ 이다.

$\mathrm{YSZ}$ 피막층의 표면 및 단면을 $\mathrm{SEM}$ 으로 관찰한 사진을 Fig. 2에 나타내었다. 피막층은 표면 기공이나 균열이 없이 치밀하게 형성되었지만, 다소 거친 표면 형상을 보여주고 있다. 이러한 망상 구조의 특징은 $\mathrm{AD}$ 법에 의해 형성된 세 라믹 코팅층에서 흔히 나타나는 구조이다(Fig. 2(a)). 피막 층의 두께는 약 $5 \mu \mathrm{m}$ 이며, 내부 기공이나 균열 없이 $\mathrm{Al}$ 합 금 기판 위에 균일하게 증착 되었다(Fig. 2(b)). 유사한 $\mathrm{AD}$ 법 에 의해 증착된 수산화아파타이트(HA)의 경우 이론 밀도 의 $98.5 \%$ 에 해당하는 막을 얻었다는 보고가 있지만, 기 체투과실험과 같은 보다 정밀한 실험을 통해 증착막의 밀 도 측정이 요구된다. ${ }^{20)}$ 기존의 연구 결과에 의하면, 기판에 대한 $\mathrm{AD}$ 코팅층의 접착 강도는 약 20 에서 $50 \mathrm{MPa}$ 로 보 고되었으며 이는 $\mathrm{AD}$ 코팅층과 기판 사이에 존재하는 앵커 링 층에 의해서 기인된 것으로 알려져 있다. ${ }^{14,18)} \mathrm{YSZ}$ 피막 층의 미세 조직적인 특성을 상세히 관찰하기 위해, 고분해 능 투과 전자 현미경(HRTEM)을 이용하여 YSZ 코팅층의 미세구조를 관찰하였고 그에 대한 결과를 Fig. 3에 나타내 었다. Fig. 3(a)에 보여지는 고배율의 TEM의 명시야상(bright field image)으로부터 결정립 혹은 결정은 명확하게 구분되 지 않지만, spot과 ring 형태의 회절 패턴은 제한시야회절

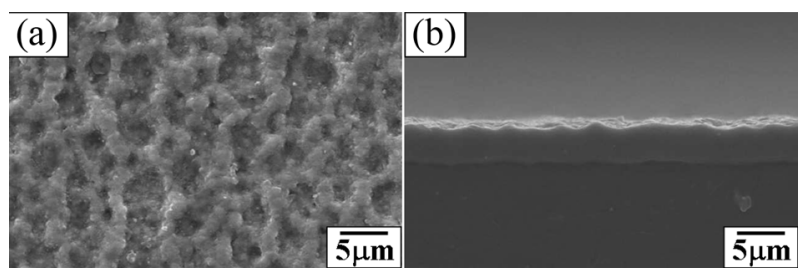

Fig. 2. SEM micrographs of (a) surface morphology and (b) cross-sectional view for YSZ coated AA1050 Al alloy.
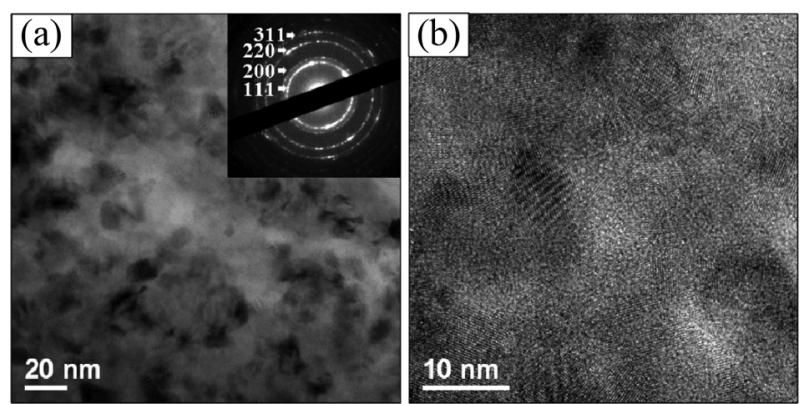

Fig. 3. (a) High magnification and (b) high resolution TEM images of the YSZ coated AA1050 Al alloy. The inset of (a) is the SAED patterns of the YSZ coating. 
패턴(SAED, selected area diffraction pattern)에 나타났고 Fig. 3(b)의 고분해능 투과 전자 현미경 사진으로부터 결정립의 격자 주름이 확실히 들어났다. SAED의 Ring pattern과 HRTEM 사진의 격자 패턴에서 얻어진 결정 격자에 대한 정보는 cubic 구조의 YSZ 상과 완벽히 일치했다. HRTEM 사진으로부터 대부분의 피막층은 $10 \mathrm{~nm}$ 이하의 나노 결정 립으로 구성되어 있고 이는 XRD 패턴으로부터 계산된 결 정립의 크기와 거의 일치한다. 결론적으로, 불규칙적인 방위 를 갖는 나노 다결정질의 $\mathrm{YSZ}$ 코팅층이 $\mathrm{AA} 1050 \mathrm{Al}$ 합 금 위에 성공적으로 증착되었다.

\subsection{YSZ 코팅된 $\mathrm{AA} 1050 \mathrm{Al}$ 합금의 부식 특성}

$\mathrm{YSZ}$ 코팅된 $\mathrm{AA} 1050 \mathrm{Al}$ 합금의 부식 특성을 평가하기 위 해 상온의 $3.5 \mathrm{wt} \% \mathrm{NaCl}$ 수용액과 $0.5 \mathrm{M} \mathrm{H}_{2} \mathrm{SO}_{4}$ 수용액에서 전기화학적인 동전위 분극 실험을 행하였고 그 결과를 Fig. 4 및 Fig. 5에 나타내었다. YSZ 코팅층이 알루미늄 합 금의 전기화학적 부식 특성에 미치는 영향을 쉽게 파악하기 위하여 코팅되지 않은 $\mathrm{AA} 1050 \mathrm{Al}$ 합금에 대한 동전위 분극 실험 결과도 첨부하였다. 각각의 분극 곡선의 Tafel 영역 $( \pm 200 \mathrm{mV})$ 에서 얻어진 양극 $\mathrm{Tafel}$ 기울기 $\left(\beta_{a}\right)$, 음극 Tafel 기울기 $\left(\beta_{c}\right)$, 부식전위 $\left(E_{c o r r}\right)$, 부식전류밀도 $\left(I_{c o r r}\right)$ 는 Table 3 에 나타내었다. $\mathrm{NaCl}$ 수용액에서의 코팅되지 않은 $\mathrm{AA} 1050$ 기판은 $-760 \mathrm{mV} / \mathrm{SCE}$ 의 부식전위와 $0.5 \mu \mathrm{m} / \mathrm{cm}^{2}$ 의 부식전 류밀도를 나타내었으며, 뚜렷한 부동태 거동을 보이지 않

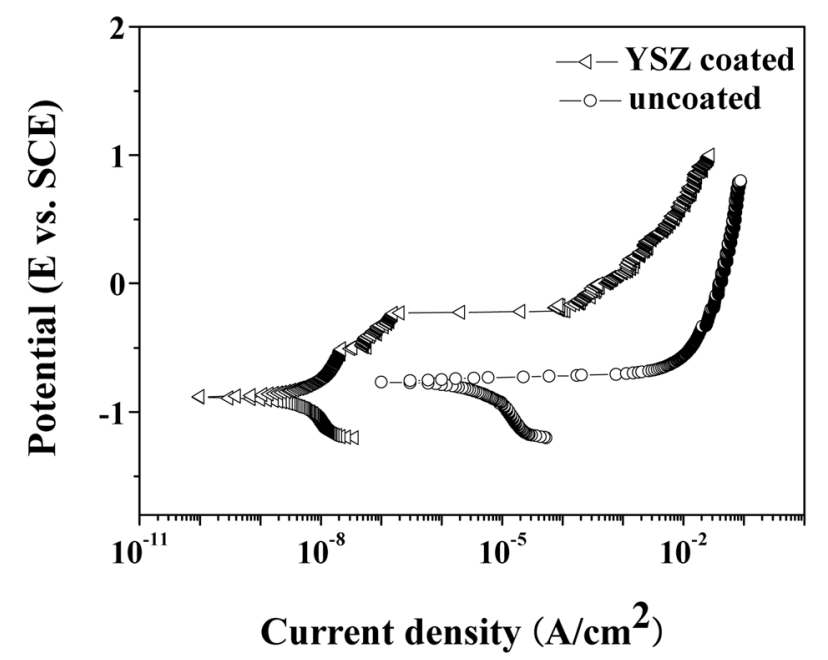

Fig. 4. Potentiodynamic polarization curves of the YSZ coated AA1050 Al alloys measured in $3.5 \mathrm{wt} \% \mathrm{NaCl}$ solution.

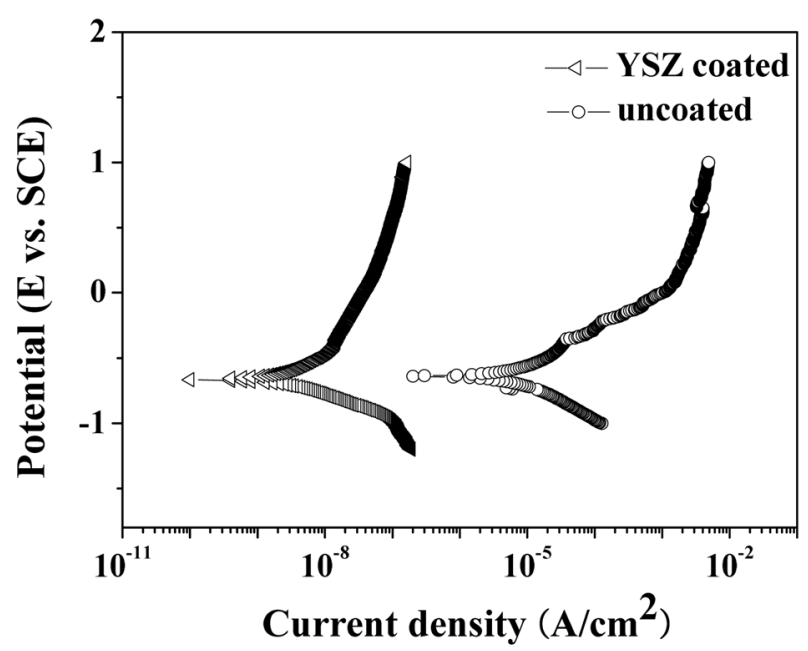

Fig. 5. Potentiodynamic polarization curves of the $\mathrm{YSZ}$ coated AA1050 Al alloys measured in $0.5 \mathrm{M} \mathrm{H}_{2} \mathrm{SO}_{4}$ solution.

고 포텐셜의 증가에 따라 전류밀도는 크게 증가한다. 본 연 구에서 확인된 $\mathrm{NaCl}$ 수용액에서의 $\mathrm{AA} 1050 \mathrm{Al}$ 합금의 동전 위 분극 곡선의 특징은 이전에 보고된 문헌과 비슷하다. ${ }^{21)}$ $\mathrm{YSZ}$ 코팅된 $\mathrm{Al}$ 합금의 부식전위는 $-882 \mathrm{mV} / \mathrm{SCE}$ 로 코팅 되지 않은 시편에 비해 약 $120 \mathrm{mV}$ 낮지만, 부식속도를 나 타내는 부식전류밀도는 $2.5 \mathrm{nA} / \mathrm{cm}^{2}$ 로 순수한 $\mathrm{AA} 1050 \mathrm{Al}$ 합금에 비해 $1 / 200$ 의 값을 보였다. 더욱이 활성영역의 $E_{\text {corr }}$ 에서부터 약 $-200 \mathrm{mV} / \mathrm{SCE}$ 까지 전류밀도가 크게 증가하지 않는 부동태 거동을 나타내고 있다. 황산 용액에서의 AA1050 $\mathrm{Al}$ 기판은 약 $-657 \mathrm{mV} / \mathrm{SCE}$ 의 부식전위와 $4300 \mathrm{nA} / \mathrm{cm}^{2}$ 의 전류밀도로, $\mathrm{NaCl}$ 수용액에서 비해서 부식전위는 약 $100 \mathrm{mV}$ 증가하였지만 부식전류밀도는 약 10 배 정도 증가했다. 이는 황산 용액에서 $\mathrm{AA} 1050 \mathrm{Al}$ 합금의 부식 반응이 좀 더 빠 르게 일어나는 것을 의미한다. 실제로, 활성영역에서 두 시편을 제거한 후 표면을 확인 한 결과, $\mathrm{NaCl}$ 수용액에서 보다 황산 용액으로부터 제거된 시편의 표면에서 공식 흔 적이 더 넓게 분포하고 있는 것을 확인 할 수 있었다. 코 팅되지 않은 시편과 비교해서, Tafel 구간에서 얻어진 YSZ 코팅된 시편의 부식전위는 약 $20 \mathrm{mV} / \mathrm{SCE}$ 정도 증가했고 부식전류밀도 값은 $1 / 2000$ 로 매우 낮아졌다. $\mathrm{NaCl}$ 수용액 에서 얻어진 결과와 비교하면, YSZ 코팅된 시편의 부식전 위는 $100 \mathrm{mV}$ 향상되었으나 부식전류밀도는 거의 동일한 값을 나타내고 이는 활성 구간에서 비슷한 부식특성을 나 타내는 것을 의미한다. 그러나 $\mathrm{OCP}$ 근처의 활성구간을

Table 3. Equivalent Circuit Data for YSZ Coated AA1050 Al Alloys Measured in (a) $3.5 \mathrm{wt} \% \mathrm{NaCl}$ and (b) $0.5 \mathrm{M} \mathrm{H}_{2} \mathrm{SO}_{4} \mathrm{Solutions}$

\begin{tabular}{|c|c|c|c|c|c|c|c|}
\hline & $\mathrm{R}_{\mathrm{s}}\left(\Omega \mathrm{cm}^{2}\right)$ & $\mathrm{R}_{\text {coat }}\left(\mathrm{M} \Omega \mathrm{cm}^{2}\right)$ & $\mathrm{CPE}_{\text {coat }}\left(\times 10^{-9} \Omega^{-1} \mathrm{~s}^{\mathrm{n}} \mathrm{cm}^{-2}\right)$ & $\mathrm{n}_{\mathrm{hF}}$ & $\mathrm{R}_{\text {polar }}\left(\mathrm{M} \Omega \mathrm{cm}^{2}\right)$ & $\mathrm{CPE}_{\mathrm{dl}}\left(\times 10^{-9} \Omega^{-1} \mathrm{~s}^{\mathrm{n}} \mathrm{cm}^{-2}\right)$ & $\mathrm{n}_{\mathrm{IF}}$ \\
\hline (a) & 9 & 0.003 & 6.9 & 0.99 & 8.3 & 46.8 & 0.90 \\
\hline (b) & 25 & 0.9 & 11.8 & 0.97 & 25 & 3.5 & 0.90 \\
\hline
\end{tabular}


벗어나면 두 전해용액에서 얻어진 분극 곡선의 모양은 매우 다르게 나타난다. $\mathrm{NaCl}$ 수용액에서의 $\mathrm{YSZ}$ 코팅된 시료의 anodic 분극 곡선에서 전위에 따른 전류밀도는 크게 변하 지만, 황산 용액의 YSZ 코팅 시료의 전류밀도는 전위에 따 라서 비교적 일정한 값을 나타낸다. 특히, $\mathrm{NaCl}$ 수용액에서 는 약 $-0.2 \mathrm{~V} / \mathrm{SCE}$ 의 전위 이상이 되면 전류밀도는 급격하게 증가하는 것에 비해, 황산 용액에서는 활성 영역을 벗어난 초기 전위 $(-450 \mathrm{mV} / \mathrm{SCE})$ 에서 전류밀도는 약 $10 \mathrm{nA} / \mathrm{cm}^{2}$ 로 부식전류밀도와 비슷하고 동전위 실험 동안 비교적 일정 하게 유지되었다. 유기 혹은 무기 코팅된 금속의 분극 곡선 에서 어떤 임계 전위에서 전류밀도가 급격하게 증하는 전 위를 pitting breakdown potential $\left(\mathrm{E}_{\mathrm{bd}}\right)$ 라고 하며, ${ }^{2,23)}$ 전류 밀도의 증가는 부식 반응에 의해서 코팅층과 기판 사이에 공식 결함의 형성으로 기인된 것으로 알려져 있다. 더욱이, 황산 용액내의 $\mathrm{YSZ}$ 코팅된 시료는 $1 \mathrm{mV} / \mathrm{SCE}$ 전위에서 약 $0.16 \mu \mathrm{m} / \mathrm{cm}^{2}$ 의 낮은 전류밀도를 보이지만, 동일 전위에 서 $\mathrm{NaCl}$ 수용액에서의 시편은 모재와 비슷한 전류밀도를 나타낸다. 동전위 실험 결과, $\mathrm{YSZ}$ 코팅층은 $\mathrm{NaCl}$ 수용액 과 황산 용액에 대한 $\mathrm{AA} 1050 \mathrm{Al}$ 합금의 부식 저항성을 크 게 증가시켰으며, 특히, $\mathrm{YSZ}$ 코팅된 $\mathrm{AA} 1050 \mathrm{Al}$ 합금은 황 산 용액에서 공식 부식 현상이 없는 매우 안정한 부동태 거 동을 보이는 것으로 확인 되었다.

$\mathrm{AC}$ 임피던스 실험을 $3.5 \mathrm{wt} \% \mathrm{NaCl}$ 수용액과 $0.5 \mathrm{M} \mathrm{H}_{2} \mathrm{SO}_{4}$
수용액에서 실시하였고, 그 결과를 Figs. 6과 7에 나타내 었다. $\mathrm{NaCl}$ 수용액과 황산 용액에서, 저주파수 영역의 코팅 되지 않은 $\mathrm{Al}$ 합금의 임피던스 값은 각각 $~ 10^{4} \Omega \mathrm{cm}^{2}$ 과 $\sim 10^{3} \Omega \mathrm{cm}^{2}$ 로 황산 용액에서 더 낮은 저항을 나타냈다. 저 주파수 영역의 임피던스 값은 시료의 부식 저항 특성을 판 단하는 값으로 코팅되지 않은 시편이 황산 용액에서 보다 낮은 부식 특성을 갖는 것을 의미하며, 이것은 동전위 실 험에서 보여지는 전류밀도와 비슷한 경향을 나타낸다. 반 면에, $\mathrm{NaCl}$ 수용액에서 측정된 $\mathrm{YSZ}$ 코팅된 $\mathrm{AA} 1050 \mathrm{Al}$ 합금의 임피던스는 $\sim 10^{7} \Omega \mathrm{cm}^{2}$ 로 기판에 비해서 약 1000 배 정도 크며, 황산 용액의 경우, 코팅된 시료의 임피던스는 기판에 비해 약 10000 배 정도 향상되었다. 이러한 값은 anodizing법에 의해 표면 처리된 AA1050 Al 합금의 값에 상응하거나 좀 더 우수한 값이며, ${ }^{24,25)}$ 이러한 높은 부식 저항성은 결함이 없는 치밀한 YSZ 코팅층이 AA1050 기 판과 강하게 결합되었기 때문으로 판단된다. 코팅층의 특성 과 부식 특성을 보다 자세히 고찰하기 위해서, EIS 결과를 적절한 등가회로 모델을 이용하여 도식(fitting)하였고 관 련된 모델을 Fig. 8에 나타내었다. 적용한 등가회로는 폴리 머 혹은 세라믹 코팅된 금속에 널리 적용되는 모델로서, $22,26,27)$ 두 개의 시정수(time constant)로 구성되었다. 여기서, $R_{\mathrm{s}}$ 는 기준전극과 작업전극 사이의 용액저항을, $R_{\mathrm{coat}}$ 는 코팅층의 저항으로 코팅층을 통과하는 이온들의 전도 흐름에 따른
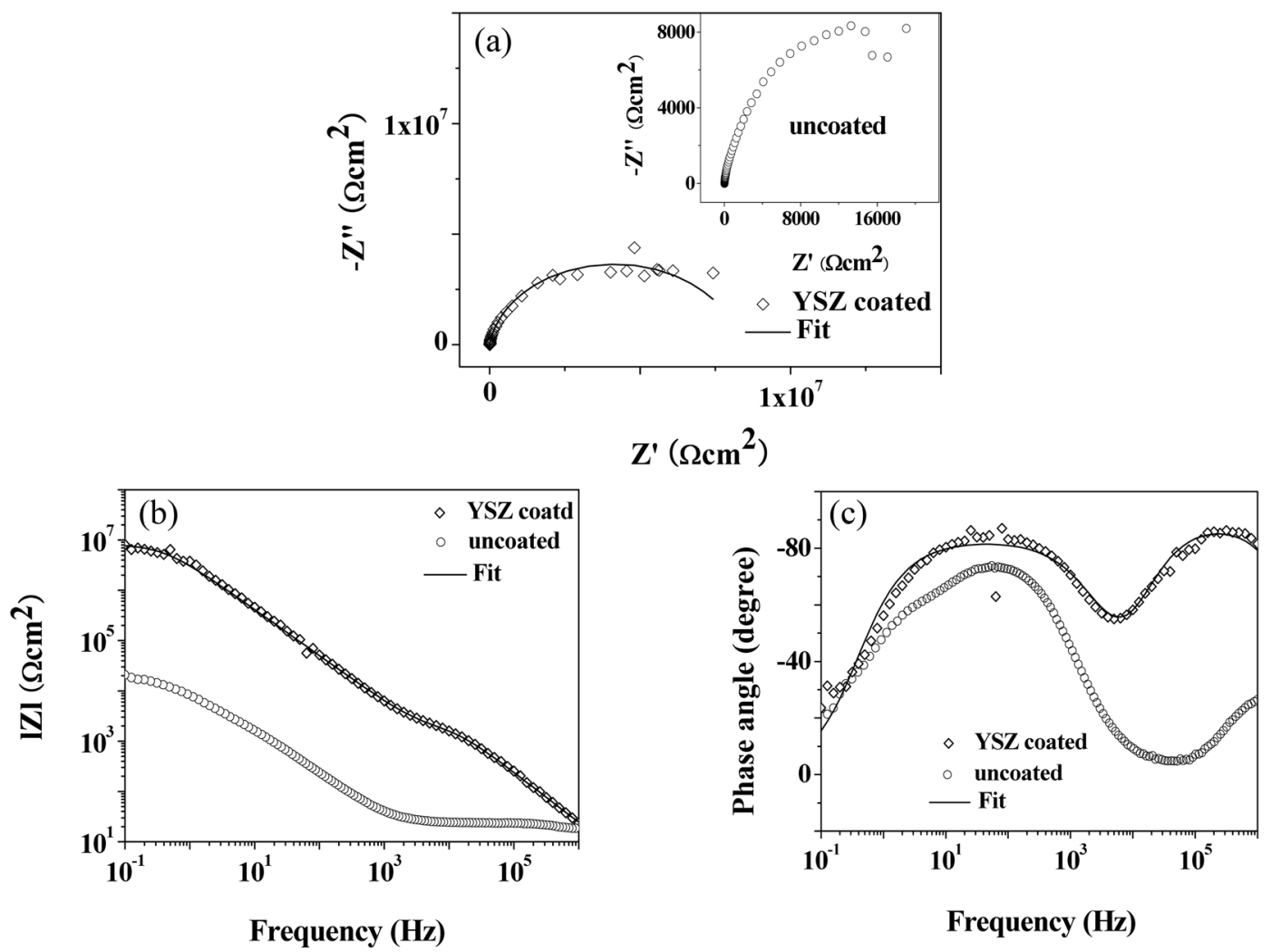

Fig. 6. (a) Nyquist and [(b) and (c)] Bode plots of the uncoated and YSZ coated AA1050 Al alloys obtained in $3.5 \mathrm{wt} \% \mathrm{NaCl}$ solution. 

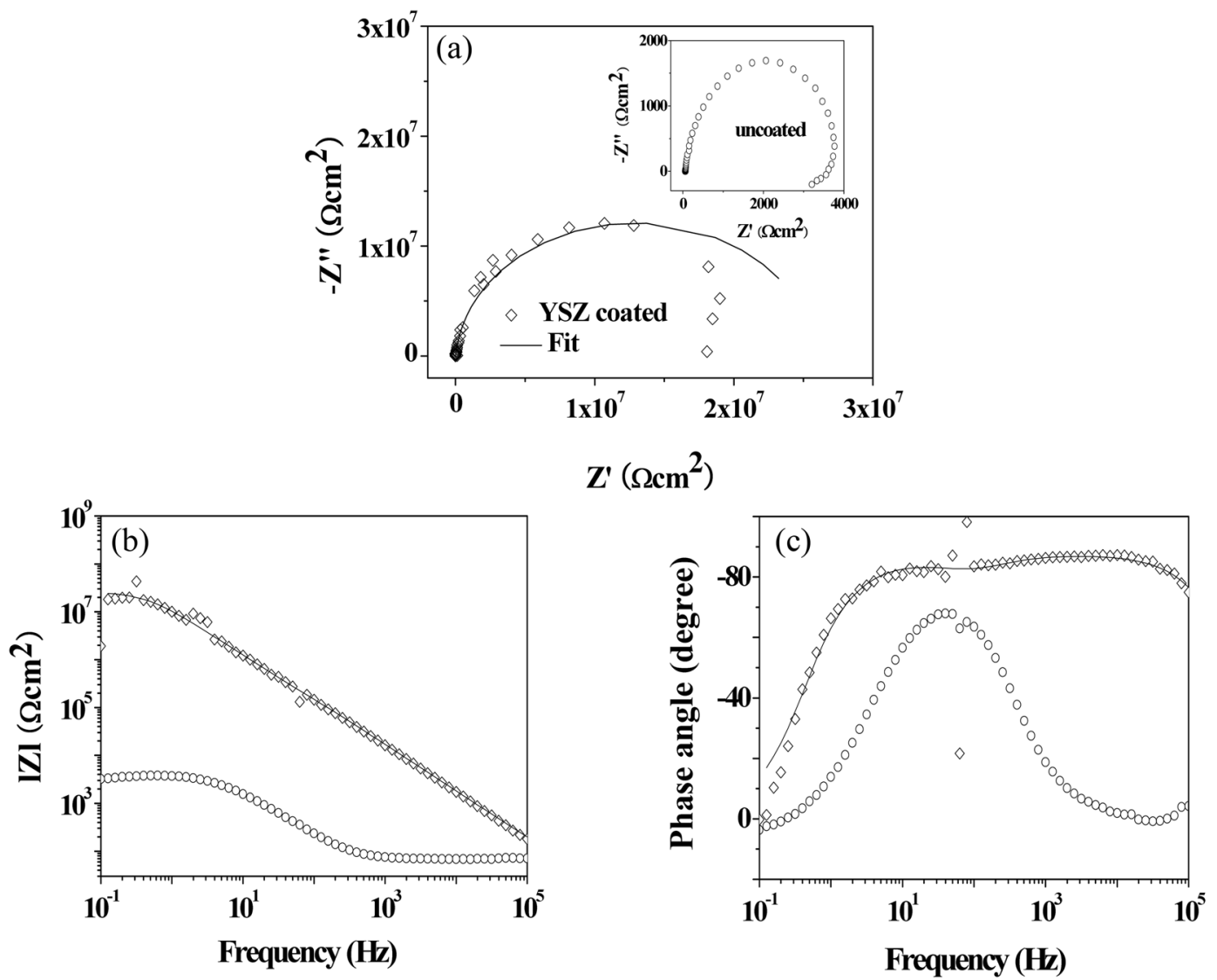

Fig. 7. (a) Nyquist and [(b) and (c)] Bode plots of the uncoated and YSZ coated AA1050 Al alloys obtained in $0.5 \mathrm{M} \mathrm{H}_{2} \mathrm{SO}_{4}$ solution.

저항에서 기인되는 값으로, 코팅층의 constant phase element $\left(\mathrm{CPE}_{\mathrm{coat}}\right)$ 와 병렬로 연결되어 있다. $R_{\mathrm{polar}}$ 은 코팅층/금속 계 면에서의 분극저항으로, 코팅층/금속 계면에서의 이중층 (double layer)의 constant phase element $\left(\mathrm{CPE}_{\mathrm{dl}}\right)$ 과 병렬로 연결되어 있다. 이 모델에서, CPE는 복잡한 dispersion을 보 이는 시스템에서 비이상적인 거동을 power fraction을 사용 하여 어드미턴스를 표현하는 것이다. ${ }^{28)} \mathrm{CPE}$ 성분은 실제 $\mathrm{EIS}$ data를 도식하는데 매우 유용하고 $\mathrm{CPE}$ 성분인 어드미턴스 $(Y)$ 에 대해서 $\left[Y_{\mathrm{CPE}}(\omega)=1 / \mathrm{Z}_{\mathrm{CPE}}=Q_{\mathrm{a}}(j \omega)^{\mathrm{n}}\right]$ 과 같은 식으로 표 현된다. ${ }^{29)} \mathrm{Fig}$. 8에 제시된 등가회로를 이용하여 도식한 data는 측정된 EIS 데이터와 대체로 일치했으며, 관련된 등가회로 성분의 도식 값은 Table 3에 나타내었다. Fig. 6(C) 의 $\mathrm{NaCl}$ 수용액에서 얻어진 Bode phase angle 그래프로 부터, $10^{5} \mathrm{~Hz}$ 와 $10^{1} \mathrm{~Hz}$ 의 주파수 영역에서 두 개의 시정수가 명확하게 구분되며 이는 두 개의 $\mathrm{CPE}$ 성분에 대한 특징 을 나타낸다. Fig. 6(B)의 Magnitude bode plot로부터, 두 개의 저항 성분이 중간 주파수 $\left(10^{3} \sim 10^{4} \mathrm{~Hz}\right)$ 영역과 저 주 파수 $\left(\sim 10^{-1} \mathrm{~Hz}\right)$ 영역에서 명확하게 나타나고 이들은 각각 각각 $R_{\text {coat }}$ 과 $R_{\text {polar }}$ 로 구분된다. 반면에, 황산 용액에서 측 정된 $\mathrm{Bode}$ plot의 경우, $\mathrm{NaCl}$ 수용액과 같이 시정수와 저항 성분이 분명하게 구분되어 지지 않는다. 그러나 Table 3 에

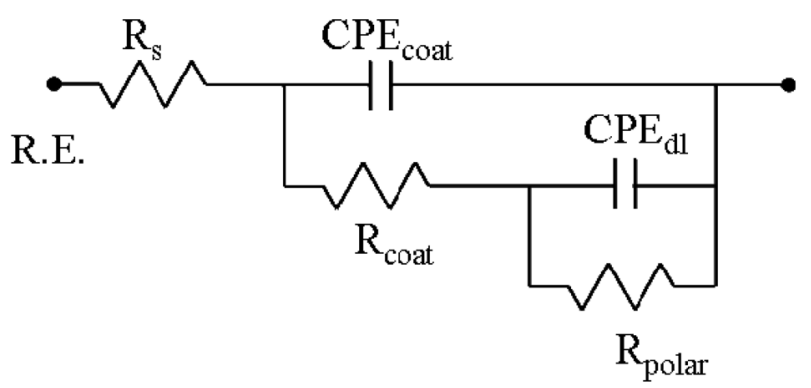

Fig. 8. Equivalent circuit for fitting the impedance data of the YSZ coated AA1050 Al alloys.

도식된 결과에 따르면, $\mathrm{NaCl}$ 수용액의 시편과 비슷한 부식 거거동을 하는 것으로 판단된다. 두 용액에서의 $R_{\mathrm{coat}}$ 을 비 교하면, $\mathrm{NaCl}$ 수용액에서의 $R_{\text {coat }}\left(\sim 3 \mathrm{k} \Omega \mathrm{cm}^{2}\right)$ 은 황산 용액 에서 측정된 $R_{\text {coat }}\left(900 \mathrm{k} \Omega \mathrm{cm}^{2}\right)$ 에 비해 약 300 배 정도 낮은 값을 보인다. 동전위 결과와 비교해서 고찰해 보면, $\mathrm{NaCl}$ 수용액에서 보이는 낮은 $R_{\text {coat }}$ 은 부식성의 $\mathrm{Cl}^{-}$이온의 영 향으로 코팅층 표면 혹은 내부에 발생한 기공 및 균열과 같 은 미세 결함에서 기인된 것으로 여겨지고 반면, 황산 용 액에서의 높은 코팅저항과 동전위 실험에서의 부동태 거동 

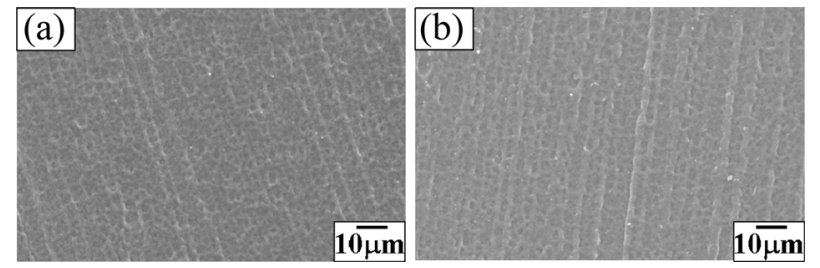

Fig. 9. SEM micrographs of surface morphology for the YSZ coated AA1050 Al alloys after EIS test in (a) $\mathrm{NaCl}$ and (b) $\mathrm{H}_{2} \mathrm{SO}_{4}$ solutions.

을 고려하면, $\mathrm{YSZ}$ 코팅층은 용액 내에 존재하는 $\mathrm{SO}_{4}{ }^{2-}$ 과 같은 부식성의 이온에 대해서 매우 안정한 것으로 판단 된다. 그러나 EIS 실험을 실시한 이후에 YSZ 코팅층의 표면을 관찰한 결과, $\mathrm{NaCl}$ 용액에서 실험한 코팅층 표면 에서도 뚜렷한 변화를 발견할 수 없었으며, 부식 생성물 혹 은 pit와 같은 부식 현상도 존재하지 않았다(Fig. 9). 게다 가, $\mathrm{YSZ}$ 코팅된 $\mathrm{Al}$ 합금의 분극저항은 두 용액 모두에서 $10^{7} \Omega \mathrm{cm}^{2}$ 이상이며, 이와 같은 높은 분극 저항은 $\mathrm{YSZ} / \mathrm{Al}$ 합 금 기판의 경계가 용액에 존재하는 부식성의 이온 $\left(\mathrm{Cl}^{-}\right.$혹 은 $\mathrm{SO}_{4}{ }^{2-}$ )의 공격으로부터 기판을 보호하는 barrier 특성 을 갖는 것을 의미한다. 그러나 두 용액에서의 YSZ 코팅층 의 부식 특성을 보다 명확하게 고찰하고, YSZ 코팅층에 존 재하는 결함 등의 효과를 고찰하기 위해서는 장기 안정성 에 대한 실험이 추가로 요구된다.

\section{4. 결 론}

본 연구에서는 최근에 개발된 상온 세라믹 코팅 기술인 $\mathrm{AD}$ 법을 $\mathrm{AA} 1050 \mathrm{Al}$ 합금에 대해 최초로 적용하였으며, 전기화학적 실험을 통해서 코팅된 $\mathrm{AA} 1050 \mathrm{Al}$ 합금의 부식 특성을 $3.5 \mathrm{wt} \% \mathrm{NaCl}$ 과 $0.5 \mathrm{M} \mathrm{H}_{2} \mathrm{SO}_{4}$ 수용액에서 고찰하 였다. 이상적인 $\mathrm{AD}$ 공정 조건 하에서 내부 및 외부에 결 함이 없는 $5 \mu \mathrm{m}$ 두께의 $\mathrm{YSZ}$ 코팅층이 $\mathrm{AA} 1050 \mathrm{Al}$ 합금에 성공적으로 형성되었으며, 코팅층은 약 $10 \mathrm{~nm}$ 크기의 cubic 구조의 YSZ 나노 결정립으로 구성되었다. 동전위 실험을 통 해서, YSZ 코팅된 $\mathrm{Al}$ 합금은 코팅되지 않은 시료에 비해서 비슷한 부식전위를 보이지만, 부식전류밀도는 약 300배에서 2000 배 정도 낮아졌다. 특히, 황산 용액에서 측정된 코팅 된 시료의 양극 분극 거동은 동전위 실험 동안 $<10^{-7} \mathrm{~A} / \mathrm{cm}^{2}$ 의 낮은 전류 밀도를 유지하는 부동태 특성을 보였다. EIS 결과를 통해 확인된 코팅된 $\mathrm{AA} 1050 \mathrm{Al}$ 합금 의 분극저 항은 $\mathrm{NaCl}$ 수용액에서 약 $10^{6} \Omega \mathrm{cm}^{2}$, 황산 용액에서 약 $10^{7} \Omega \mathrm{cm}^{2}$ 로 매우 높은 저항값을 나타냈다. 동전위 실험 결 과와 $\mathrm{EIS}$ 결과를 바탕으로, $\mathrm{AD}$ 방법으로 형성된 $\mathrm{YSZ}$ 코팅 층은 수용액 속에 존재하는 부식성 이온 $\left(\mathrm{Cl}^{-}\right.$와 $\left.\mathrm{SO}_{4}{ }^{2-}\right)$ 의 부식 공격으로부터 $\mathrm{AA} 1050 \mathrm{Al}$ 합금을 매우 효과적으로 보 호할 수 있는 것으로 판단된다. 이번 연구를 바탕으로, $\mathrm{AD}$
기술은 다양한 알루미늄 합금에 $\mathrm{Al}_{2} \mathrm{O}_{3}, \mathrm{TiO}_{2}, \mathrm{CeO}_{2}, \mathrm{MgF}_{2}$ 등과 같은 기능성 세라믹 물질을 상온에서 코팅하는데 적용 가능할 것으로 판단되며, 향후 모재의 부식 특성을 비롯한 기계적, 전기적, 화학적 특성을 더욱 개선 시킬 수 있을 것으로 기대된다.

\section{Acknowledgment}

본 연구는 한국연구재단을 통해 교육과학기술부의 세 계수준의 연구중심대학육성사업(WCU)으로부터 지원받아 수행 되었습니다 (R31-2008-000-10075-0). 재료연구소의 저 자들은 재료연구소 일반사업 “신성장동력 기반 분말소재 신기술 개발 및 보급사업”으로부터 지원받았으며 이에 감 사합니다.

\section{REFERENCES}

1. C. Vargel, "Corrosion of Aluminium," pp. 9-16, 88-109, and 149-62, Elsevier Science, San Diego, 2004.

2. M. Pourbaix, "Atlas of Electrochemical Equilibria in Aqueous Solution," pp. 168-76, $2^{\text {nd }}$ English ed. National Association of Corrosion Engineers, Houston, 1974.

3. J. R. Davis, "Corrosion of Aluminium and Aluminium Alloys,” pp. 25-67, ASM International, Materials Park, OH, 1999.

4. R. L. Twite and G. P. Bierwagen, "Review of Alternatives to Chromate for Corrosion Protection of Aluminium Aerospace Alloys," Prog. Org. Coat., 33 91-100 (1998).

5. J. Zhao, R. L. McCreery, and G. Frankel, "Corrosion Protection of Untreated AA-2024-T3 in Chloride Solution by a Chromate Conversion Coating Monitored with Raman Spectroscopy," J. Electrochem. Soc., 145 2258-64 (1998).

6. N. B. Dahotre, P. Kadolkar, and S. Shah, "Refractory Ceramic Coatings: Processes, Systems and Wettability/Adhesion," Surf. Interface Anal., 31 659-72 (2001).

7. H. S. Ryu, J. Ryu, D.-S. Park, and S.-H. Hong, "Electrochemical Corrosion Properties of Nanostructured YSZ Coated AZ31 Magnesium Alloy Prepared by Aerosol-Deposition," $J$. Electrochem. Soc., 158 C23-28 (2011).

8. F. Andreatta, P. Aldighieri, L. Paussa, R. Di Maggio, S. Rossi, and L. Fedrizzi, "Electrochemical Behavior of $\mathrm{ZrO}_{2}$ Sol-Gel Pre-treatments on AA6060 Aluminium Alloy," J. Elctrochim. Acta., 52 7545-55 (2007).

9. G. Gusmano, G. Montesperelli, M. Rapone, G. Padeletti, A. Cusm, S. Kaciulis, A. Mezzi, and R. Di Maggio, "Zirconia Primers for Corrosion Resistant Coatings," Surf. Coat. Technol., 201 5822-28 (2007).

10. H. Chen, Y. Zhang, and C. Ding, "Tribological Properties of Nanostructured Zirconia Coatings Deposited by Plasma Spraying," Wear, 253 885-93 (2002).

11. X. F. Yang, D. E. Tallman, V. J. Gelling, G. P. Bierwagen, L. S. Kasten, and J. Berg, "Use of Sol-Gel Conversion coating for Aluminum Corrosion Protection," Surf. Coat. Technol., 140 44-50 (2001). 
12. M. L. Zheludkevich, R. Serra, M. F. Montemor, K. A. Yasakau, I. M. Miranda Salvado, and M. G. S. Ferreira, "Nanostructure Sol-Gel Coatings Doped with Cerium Nitrate as Pre-treatments for AA2024-T3 Corrosion Protection Performance," Electrochim. Acta, 51 208-17 (2005).

13. O. Zubillaga, F. J. Cano, I. Azkarate, I. S. Molchan, G. E. Thompson, and P. Skeldon, "Anodic Films Containing Polyaniline and Nanoparticles for Corrosion Protection of AA2024T3 Aluminium Alloy," Surf. Coat. Technol., 203 1494-501 (2009).

14. J. Akedo, "Room Temperature Impact Consolidation (RTIC) of Fine Ceramic Powder by Aerosol Deposition Method and Applications to Microdevices," J. Therm. Spray Technol., 17 181-98 (2008).

15. J. Akedo, "Aerosol Deposition of Ceramic Thick Films at Room Temperature: Densification Mechanism of Ceramic Layer," J. Am. Ceram. Soc., 89 1834-39 (2006).

16. J. Akedo and M. Levedev, "Microstructure and Electrical Properties of Lead Zirconate Titanate $\left(\mathrm{Pb}\left(\mathrm{Zr}_{52} / \mathrm{Ti}_{48}\right) \mathrm{O}_{3}\right)$ Thick Films Deposited by Aerosol Deposition Method," Jpn. J. Appl. Phys., 38 5397-401 (1999).

17. M. Lebedev, J. Akedo, and T. Ito, "Substrate Heating Effects on Hardness of an a- $\mathrm{Al}_{2} \mathrm{O}_{3}$ Thick Film Formed by AerosolDeposition Method," J. Cryst. Growth, 275 e1301-e1306 (2005).

18. J. Ryu, D.-S. Park, B.-D. Hahn, J.-J. Choi, W.-H. Yoon, K.Y. Kim, and H.-S. Yun, "Photocatalytic $\mathrm{TiO}_{2}$ Thin Films by Aerosol-Deposition: From Micron-sized Particles to Nanograined Thin Film at Room Temperature," Appl. Catal., B, 83 1-7 (2008).

19. B.-D. Hahn, J.-M. Lee, D.-S. Park, J.-J. Choi, J. Ryu, W.-H. Yoon, B.-K. Lee, D.-S. Shin, and H.-E. Kim, "Mechanical and in Vitro Biological Performances of Hydroxyapatitecarbon Nanotube Composite Coatings Deposited on Ti by Aerosol Deposition," Acta Biomat., 5 3205-14 (2009).

20. B.-D. Hahn, D.-S. Park, J.-J. Choi, J. Ryu, W.-H Yoon, K.H. Kim, C. Park, and H.-E. Kim, "Dense Nanostructured
Hydroxyapatite Coating on Titanium by Aerosol Deposition," J. Am. Ceram. Soc., 92, 683-87 (2009).

21. M. Trueba and S. P. Trasatti, "Study of Al Alloy Corrosion in Neutral $\mathrm{NaCl}$ by the Pitting Scan Technique," Mater. Chem. and Phys., 121 523-33 (2010).

22. J. Liang, P. Bala Srinivasan, C. Blawert, and W. Dietzel, "Comparison of Electrochemical Corrosion Behaviour of $\mathrm{MgO}$ and $\mathrm{ZrO}_{2}$ Coatings on AM50 Magnesium Alloy Formed by Plasma Electrolytic Oxidation," Corros. Sci., 51 2483-92 (2009).

23. Y. Zhang, C. Yan, F. Wang, and W. Li, "Electrochemical Behavior of Anodized Mg Alloy AZ91D in Chloride Containing Aqueous Solution," Corros. Sci., 47 2816-31 (2005).

24. X.-H. Zhao, Y. Zuo, J.-P. Xiong, and Y.-M. Tang, "A Study on the Self-sealing Process of Anodic Films on Aluminum by EIS,” Surf. Coat. Technol., 200 6846-53 (2006).

25. T. Aerts, J.-B. Jorcin, I. De Graeve, and H. Terryn, "Comparison between the Influence of Applied Electrode and Electrolyte Temperatures on Porous Anodizing of Aluminium," Electrochim. Acta, 55 3957-65 (2010).

26. S. V. Lamaka, M. F. Montemor, A. F. Galio, M. L. Zheludkevich, C. Trindade, L. F. Dick, and M. G. S. Ferreira, "Novel Hybrid Sol-Gel Coatings for Corrosion Protection of AZ31B Magnesium Alloy," Electrochim. Acta, 53 4773-83 (2008).

27. M. Zaharescu, L. Predoana, A. Barau, D. Raps, F. Gammel, N. C. Rosero-Navarro, Y. Castro, A. Durn, and M. Aparicio, " $\mathrm{SiO}_{2}$ Based Hybrid Inorganic-organic Films Doped with $\mathrm{TiO}_{2}-\mathrm{CeO}_{2}$ Nanoparticles for Corrosion Protection of AA2024 and Mg-AZ31B Alloys," Corros. Sci., 51 1998-2005 (2009).

28. J.-B. Jorcin, M. E. Orazem, N. Pbre, and B. Tribollet, "CPE Analysis by Local Electrochemical Impedance Spectroscopy," Electrochim. Acta., 51 1473-79 (2006).

29. P. Zoltowski, "On the Electrical Capacitance of Interfaces Revealing Constant Phase Element Behaviour," J. Electroanal. Chem., 443 149-54 (1998). 